\title{
Regional trends in the timing of Alleghanian remagnetization in the Appalachians
}

\author{
John D. Miller, Dennis V. Kent \\ Lamont-Doherty Geological Observatory and Department of Geological Sciences, Columbia University, Palisades, New York 10964
}

\section{ABSTRACT}

Pole positions related to remagnetized components isolated in Appalachian limestone and redbed rock units range over about 60 m.y. of the Permian-Carboniferous apparent polar wander path for North America. Apparent ages of remagnetization are older in the southern Appalachians and younger to the north. If the remagnetizations are associated with fluids expelled during the Alleghany orogeny, then the apparent remagnetization age trend could describe the timing of thrust-sheet emplacement.

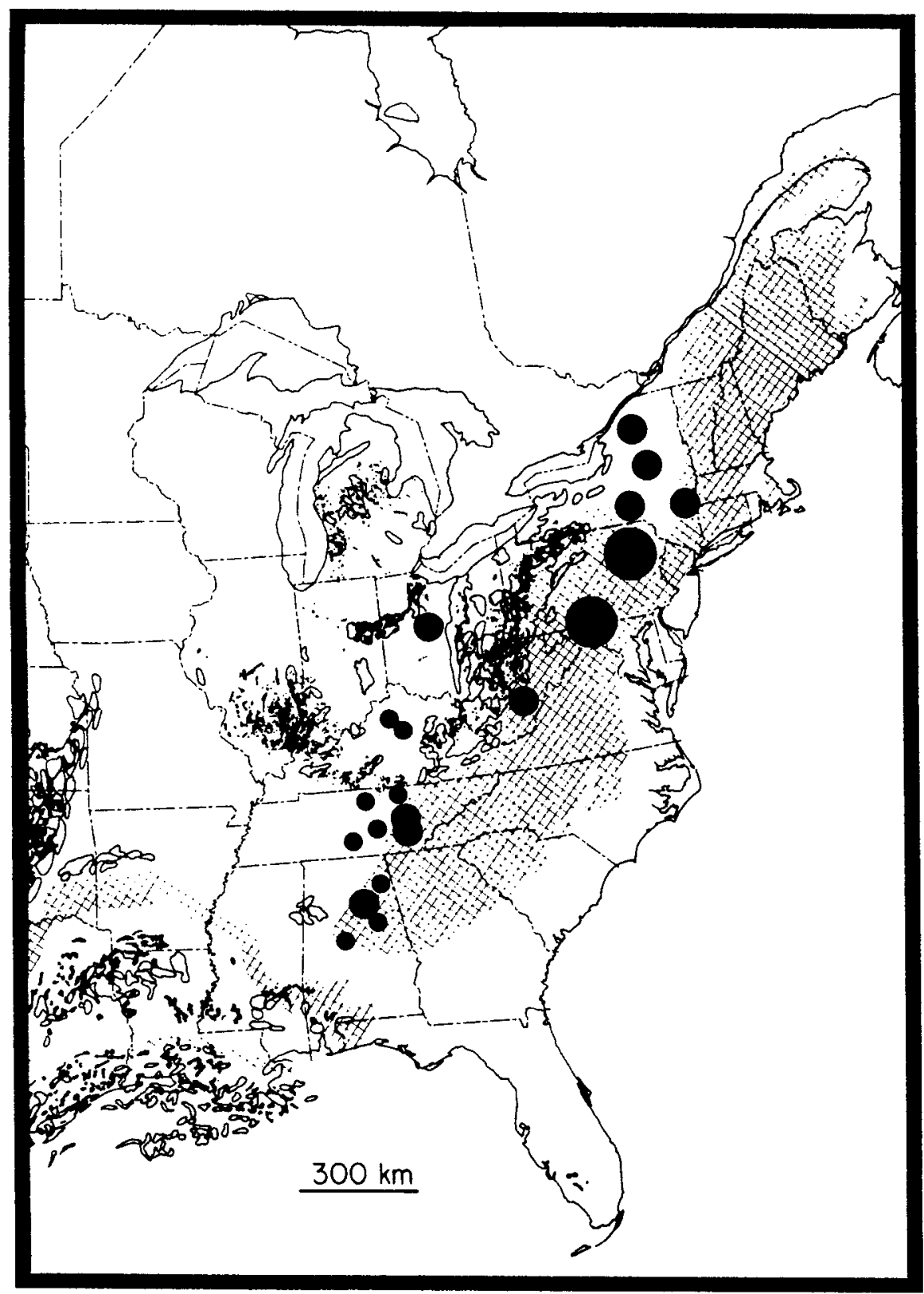

Figure 1. Simplified map from Oliver (1986) showing spatial relation of Appalachian orogenic belt (cross-hatched area) to hydrocarbon deposits (black areas) noted by Oliver as first-order evidence of fluid flow. Smallest dots are locations sampled for K/Ar or Ar/Ar dating of authigenic minerals, medium dots are locations of single paleomagnetic results, and largest dots are locations of multiple paleomagnetic studies.

\section{INTRODUCTION}

Oliver (1986) has speculated that dewatering of orogens occurs because the emplacement of thrust sheets and creation of topographic highs act to drive connate brines toward the craton. Oliver further suggested that this fluid flow is responsible for a variety of phenomena, including the remagnetization of rock units. The link between the remagnetization event and flow of hot, chemically active brines related to the Alleghany orogeny is as yet circumstantial, but the hypothesis that the distribution of hydrocarbons and ores, the variation in the rank of coals with reference to the orogen, the growth of authigenic minerals, and the remagnetization of rock units can all be explained by orogenic fluid flow provides an attractive argument for a causal relation.

The late Paleozoic remagnetizations mentioned by Oliver have been recognized from the early stages of paleomagnetic investigation in the Appalachians (e.g., Roy et al., 1967) (Fig. 1). The remagnetization, defined as a component of remanent magnetization acquired long after deposition, is now known to have affected rock types from hematite-bearing redbeds to magnetite-bearing limestones, distributed along the length of the Appalachian fold belt and into the cratonic Paleozoic sequences (Van der Voo, in prep.). In this paper we summarize our current knowledge of the well-documented late Paleozoic remagnetization in the Appalachian rock units, which were most likely affected by the Alleghany orogeny, and we describe possible implications of these data in terms of dating orogenic processes.

\section{CHARACTERISTICS OF REMAGNETIZED COMPONENTS}

Appalachian Paleozoic redbeds commonly possess two distinct magnetization components that are resolvable through the use of progressive thermal demagnetization. One component of magnetization is unblocked (removed) over laboratory temperatures of 300 to about $650{ }^{\circ} \mathrm{C}$ and is commonly termed the B component (e.g., Miller and Kent, 1988). The second, or C, component is unblocked only at temperatures of over $660^{\circ} \mathrm{C}$. These high unblocking temperatures signify hematite as the carrier of the $B$ and $\mathrm{C}$ components. The $\mathrm{C}$ component passes the fold test (it obtains its best grouping after full correction for the structural tilt of the beds) and potentially dates near to the time of deposition of the rock unit. The B component, however, is 
now generally recognized to obtain its best grouping after partial correction for the bedding tilt, suggesting that this component was acquired during the late Paleozoic Alleghanian deformation, and is therefore termed a synfolding remagnetization. Late Paleozoic remagnetization has been recognized in all the major Appalachian redbed rock units, from the $\mathrm{Up}$ per Ordovician Juniata Formation to the lower Carboniferous Mauch Chunk Formation (Table 1).

Remagnetization also affected Appalachian limestone units ranging in age from Cambrian to Carboniferous (Table 1). In contrast to the redbeds, the remagnetization component is usually the only magnetization present after removal of the overprint of Earth's present field and has unblocking temperatures of about 250 to $500{ }^{\circ} \mathrm{C}$. Remagnetization component directions most often appear to postdate folding, with the exception of the results from the Helderberg of the central Appalachians, which appear to be synfolding (Scotese et al., 1982). Magnetite has been identified as the dominant magnetic carrier in the limestones (McCabe et al., 1983).

Chemical precipitation or recrystallization of magnetic grains and thermal activation are the two main processes by which rocks can be remagnetized. Thermal effects can be related to either a viscous remanent magnetization, which results from the tendency over time of magnetic domains within preexisting grains to align with the ambient field, or a partial thermal remanent magnetization, which results from the magnetic grains acquiring a magnetization in the direction of the ambient field upon cooling from some temperature below the Curie point. A combination of these effects, a thermoviscous remanence, is most likely to have occurred in rocks such as those in question, which were buried to depths on the order of kilometres for millions of years.

We reject the hypothesis that the remagnetization observed in the redbeds and carried by hematite has a thermoviscous origin. Both theoretical studies (Pullaiah et al., 1975; Walton, 1982) and experimental work (Kent and Miller, $1987)$ indicate that ambient temperatures in excess of $600{ }^{\circ} \mathrm{C}$ would be required if these magnetizations were thermoviscous in origin. Because the areas occupied by these redbeds have not been subjected to such an elevated temperature regime, a chemical origin can be inferred by default. The fluid temperature might, however, be an important factor in determining the kinetics of the precipitation of the hematite that carries the remagnetization.

The origin of the remagnetization component in limestones is more controversial. Several workers (e.g., McCabe et al., 1983) have shown evidence that the magnetite in these rocks is diagenetic in origin, and they therefore speculated that the origin of the remagnetization is chemical. However, recent study of the thermoviscous behavior of these limestones (Kent, 1985) has

TABLE 1. REMAGNETIZATION PALEOPOLES FROM APPALACHIANS

\begin{tabular}{|c|c|c|c|c|c|c|c|c|c|}
\hline \multirow[t]{2}{*}{ Rock unit } & \multirow{2}{*}{$\begin{array}{l}\text { Rock } \\
\text { type }\end{array}$} & \multirow{2}{*}{$\begin{array}{l}\text { Rock } \\
\text { Age* }\end{array}$} & \multicolumn{2}{|c|}{ Site } & \multirow{2}{*}{$\begin{array}{l}\text { Fold } \\
\text { test } \\
\text { resultt }\end{array}$} & \multicolumn{2}{|c|}{ Pole } & \multirow{2}{*}{$\begin{array}{c}\text { A 95\# } \\
\left({ }^{\circ}\right)\end{array}$} & \multirow{2}{*}{$\operatorname{Ref} \star \star$} \\
\hline & & & $\begin{array}{r}\text { long } \\
\left({ }^{\circ} \mathrm{E}\right)\end{array}$ & $\begin{array}{l}\text { lat } \\
\text { (ON) }\end{array}$ & & $\begin{array}{l}\text { long } \\
\text { ( }\end{array}$ & $\begin{array}{l}\text { lat } \\
\text { (9N) }\end{array}$ & & \\
\hline MN (Mauch Chunk) & Redbed & EC & -76 & 41 & Syn & 112 & 50 & 6 & 1 \\
\hline MS (Mauch Chunk) & Redbed & EC & -78 & 40 & Syn & 130 & 52 & 4 & 2 \\
\hline G(Greenbrier) & Limestone & E EC & -80 & 38 & Post & 131 & 43 & 8 & 3 \\
\hline $\mathrm{CN}$ (Catskill) & Redbed & LD & -76 & 41 & Syn & 124 & 48 & 5 & 4 \\
\hline CS (Catskill) & Redbed & LD & -79 & 40 & syn & 127 & 43 & 5 & 5 \\
\hline ko(Catskill) & Redbed & LD & -74 & 42 & - & 117 & 47 & 5 & 6 \\
\hline C(Columbus) & Limestone & $\mathrm{MD}$ & -82 & 40 & - & 120 & 46 & 2 & 7 \\
\hline H (Helderberg) & Limestone & $S-D$ & -77 & 40 & Syn & 115 & 49 & 9 & 8 \\
\hline H1 (Helderberg) & Limestone & $=S-D$ & -75 & 43 & Post & 129 & 50 & 2 & 9 \\
\hline H2 (Held, onon.) & Limestone & $S-D$ & -75 & 43 & Post & 115 & 49 & 4 & 10 \\
\hline AN (Andreas) & Redbed & S-D & -74 & 41 & Syn & 122 & 58 & 5 & 11 \\
\hline $\mathrm{BN}$ (Bloomsburg) & Redbed & LS & -76 & 41 & syn & 103 & 51 & 9 & 1 \\
\hline BS (Bloomsburg) & Redbed & LS & -79 & 40 & Syn & 118 & 43 & 9 & 1 \\
\hline RM (Red Mtn) & Redbed & LS & -87 & 34 & Pre & 132 & 38 & 4 & 12 \\
\hline RH(Rose Hill) & Redbed & MS & -79 & 39 & - & 117 & 45 & 6 & 13 \\
\hline JU (Juniata) & Redbed & LO & -79 & 40 & - & 129 & 47 & 8 & 14 \\
\hline T (Trenton) & Limestone & MO & -75 & 43 & - & 127 & 53 & 3 & 15 \\
\hline M(Moccasin) & Redbed & Mo & -83 & 36 & Pre & 125 & 41 & 5 & 16 \\
\hline $\mathrm{K}($ Knox GP) & Limestone & $=\mathrm{LC}$ & -85 & 36 & - & 126 & 40 & 8 & 17 \\
\hline$N($ Nolitchucky) & Limestone & $\mathrm{LC}$ & -84 & 36 & - & 120 & 40 & - & 18 \\
\hline$A(A I$ lentown) & Limestone & $=\mathrm{LC}$ & -75 & 41 & Post & 114 & 47 & 8 & 19 \\
\hline L(Leithsville) & Limestone & & -75 & 41 & Post & 113 & 53 & $\frac{8}{10 n}$ & $\frac{19}{S-D}=$ \\
\hline \multicolumn{10}{|c|}{ 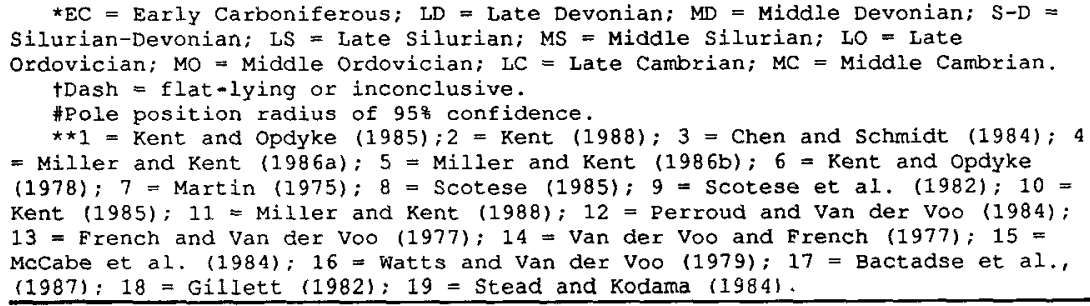 } \\
\hline
\end{tabular}

shown that thermal effects may be more potent than previously supposed and could account for the observed remagnetizations, given the elevated temperatures recorded in fluid inclusions in some Appalachian limestones (Dorobek, 1987). Hence, the distinction between a thermal or a chemical origin for the remagnetization of the limestones is not as clear as for the redbeds.

\section{TIMING OF REMAGNETIZATION}

The apparent age of remagnetization for a given rock unit can be determined by assigning the age of the closest point on the age-calibrated North American apparent polar wander (APW) path to the remagnetization pole position. In such an analysis, the choice of reference path is obviously of importance to the assigned ages. However, the late Paleozoic APW path for North America is well known and, for example, there is little difference between paths generated by sliding age window-averaging techniques, such as the path of Irving and Irving (1982), or more model-dependent paths derived from Euler pole analysis, such as that of Gordon et al. (1984). Over the period from the late Carboniferous through the Permian (or $\sim 60$ m.y.), the North American APW path covered some $30^{\circ}$ of arc. Because the $95 \%$ circles of confidence for the remagnetization poles range from $2^{\circ}$ to $10^{\circ}$ in radius, we should be able to resolve apparent remagnetization age differences of less than 20 m.y.

If all the remagnetizations occurred during the same relatively short time period, then we would expect that the remagnetization poles should form a circular distribution about some point on the APW path. Instead, the remagnetization poles show an elongate distribution from roughly 300 to $240 \mathrm{Ma}$ on the North American APW path, suggesting a period of some $60 \mathrm{~m} . \mathrm{y}$. as the duration of the remagnetization event in the Appalachians as a whole (Fig. 2).

The Appalachians trend roughly north-south; we can therefore examine first-order regional remagnetization age relations by plotting remagnetization age vs. site latitude. The remagnetization apparent age data for both the redbeds and the limestones show a general progression of decreasing age with increasing (more northerly) sampling location latitude (Fig. 3). The trends defined by the data gathered from redbeds and limestones are remarkably similar. Together, these data indicate that the remagnetizations were not synchronous over the length of the Appalachians, but were imprinted first in the southern Appalachians.

The remagnetization also appears to become younger from south to north in the Appalachians relative to folding. The few prefolding remagnetizations are from the southern Appalachians; synfolding magnetizations are commonly observed in the central region, and postfolding remagnetizations tend to be recorded in the north-central Appalachians (Table 1).

The general timing of the remagnetization is consistent with $\mathrm{K} / \mathrm{Ar}$ and $\mathrm{Ar} / \mathrm{Ar}$ ages derived from K-bentonite illitization (Elliott and Aronson, 1987; Altaner, 1985) and from authigenic feldspars (Hearn and Sutter, 1985). These data show considerable scatter, with relative age differences of up to $43 \mathrm{~m}$.y. determined for sampling localities within $100 \mathrm{~km}$ of each other, but 
the youngest ages conform to the age vs. latitude progression observed in the remagnetization. The older radiometric ages may reflect contributions from earlier diagenetic episodes.

\section{POSSIBLE COMPLICATIONS}

Folding-related strain could cause significant deflection of remanent magnetization vectors in deformed rock units, perhaps even making prefolding magnetizations appear to be synfolding (e.g., Van der Pluijm, 1987). A related possible source of error is that correct calculation of directions of synfolding magnetizations requires that the fold development be precisely reversed in the course of incremental tilt correction. It is unlikely that the simple incremental tilt correction commonly employed (e.g., Miller and Kent, 1986a) corresponds to the details of the folding of the sampled structures. However, because the same general age vs. latitude trend is observed in data from both folded and flat-lying units, folding and strain effects do not seem to be critical to the present discussion.

Remagnetization is typically regarded as a source of contamination or noise in most paleomagnetic studies. However, because we treat the remagnetization as the signal, it is pertinent to consider how effectively the remagnetization component can be isolated. As outlined above, the thermal demagnetization spectra of many of the redbeds show that the remagnetization, or $\mathrm{B}$, component is typically distributed over a broad range of unblocking temperatures, whereas the prefolding $\mathbf{C}$ magnetization is usually characterized by a higher and very narrow unblocking temperature range. However, it is possible that the more ancient $\mathrm{C}$ magnetization had a broader unblocking temperature spectrum whose lower temperature part, rather than being erased, was simply masked by the remagnetization. For example, the formation of second-generation hematite that carries the remagnetization in redbeds could leave the hematitic carrier of the original (prefolding) remanence, whether detrital or chemical in origin, effectively unchanged. Demagnetization at temperatures below the maximum unblocking temperature of the remagnetization could then be removing parts of both the remagnetization and the prefolding magnetization simultaneously. Because the remagnetization component is often referred to as overprinting the more ancient prefolding component, this complementary potential contamination of the remagnetization direction by the prefolding component could be termed an "underprinting." Magnetic underprinting is analogous to the contamination of the ${ }^{40} \mathrm{Ar} /{ }^{39} \mathrm{Ar}$ spectra of authigenic K-feldspars by the degassing of the detritral feldspar cores of the grains noted by Hearn and Sutter (1985).
Figure 2. Remagnetization pole positions compared to Permian-Carboniferous North American apparent polar wander path of Irving and Irving (1982); heavy line-30 m.y. window path used; numbers represent ages (Ma); dashed lines enclose $95 \%$ confidence level envelope about path. Abbreviations as in Table 1.

Figure 3. Apparent remagnetization ages and $\mathrm{K} / \mathrm{Ar}$ and Ar/Ar dates of authigenic minerals and alteration products vs. latitude of sampled locality in Appalachians. $R$ is correlation coefficient.
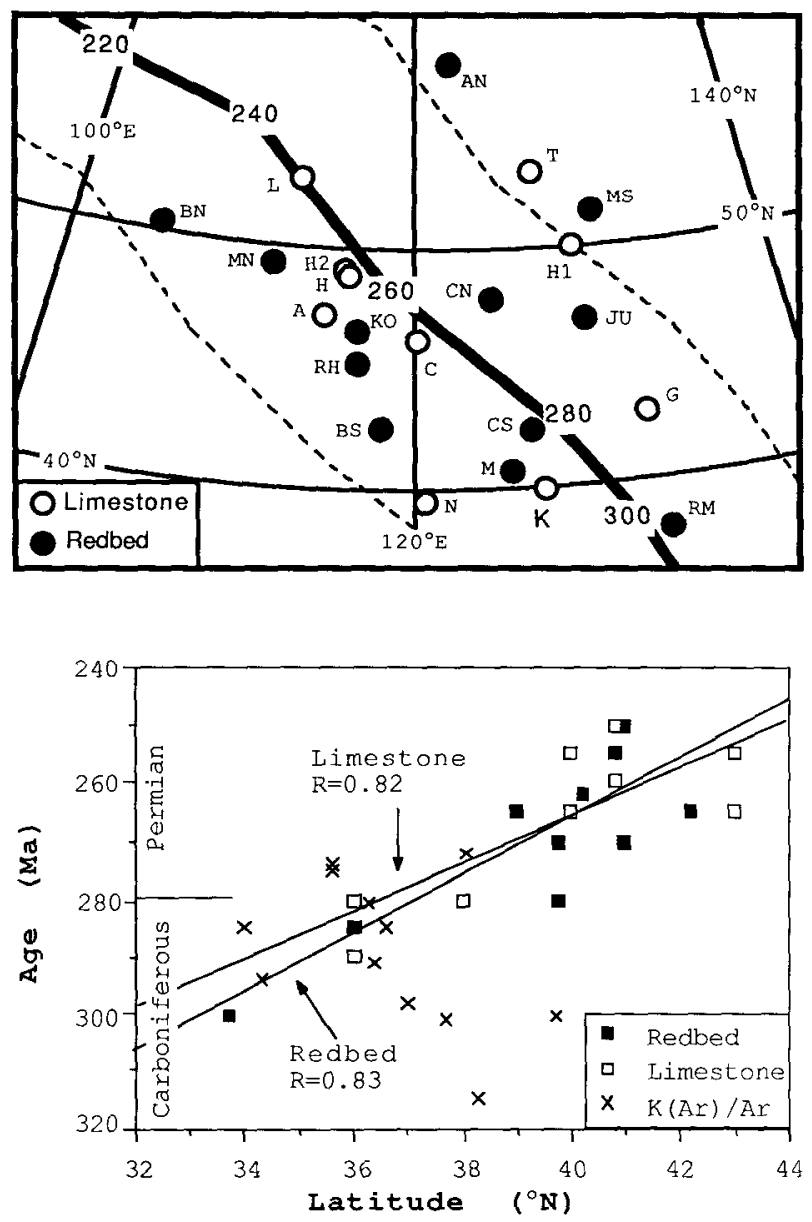

We have found it difficult to discern the effect of underprinting in component analysis of demagnetization data from individual samples, perhaps because the unblocking temperature spectra of the remagnetization and prefolding component are of similar shape over the temperature interval they overlap. However, indirect evidence that underprinting might be present can be seen in the data from the Mauch Chunk Formation (Kent and Opdyke, 1985), where remagnetization site-mean directions from the northern limb of the Pennsylvania salient appear to show a dependence on the polarity of the prefolding magnetization. For sites where the prefolding magnetization had a normal polarity, the best grouped remagnetization direction (declination $/$ inclination $=177.8^{\circ} /-9.8^{\circ}, \alpha 95$ $=8^{\circ}, N=5$ ) is about $12^{\circ}$ more negative in inclination than the best grouped direction $\left(170.7^{\circ} / 1.9^{\circ}, \alpha 95=9.4^{\circ}, N=8\right)$ for sites that had prefolding magnetizations characterized by reversed polarity. The directional discrepancy between these magnetization directions is consistent with the sense of offset that would be predicted if the preexisting magnetization biased the remagnetization direction (the effect of magnetic underprinting would be to draw the measured remagnetization component toward the noncoaxial prefolding component along the great circle connecting the two directions).

The amount of the deflection of the remagnetization vectors would depend on the relative magnitudes of the remagnetization and preAlleghanian components that are known to vary in the central Appalachians, the remagnetization being relatively stronger in the south-central region (Roy et al., 1967). Such regional variation could contribute to the apparent age trend observed in the remagnetizations. However, prefolding magnetizations are rarely preserved in Appalachian limestones and underprinting might be less of a problem in these magnetitebearing rocks for related reasons, either because the limestone lacked significant magnetite prior to remagnetization and thus had no memory of any pre-late Paleozoic magnetizations (McCabe et al., 1983), or because the remagnetization is of thermoviscous origin, the acquisition of which erased any previous magnetizations (Kent, 1985). Because both the limestones (which may be immune to underprinting) and the redbeds define similar trends, we feel that regional variation in underprinting is unlikely to fully account for the observed trend in apparent age of remagnetization. Also, severe remagnetization of the redbeds may totally overwhelm the effect of underprinting; a data set similar to that described above from the Mauch Chunk sampled in the southern limb of the salient where the remagnetization is more severe does not show an offset seen in the northern limb data. A better understanding of the mechanism of remagnetization is needed to determine how effectively the remagnetization components can be isolated. 


\section{CONCLUSIONS}

We have described what appears to be a firstorder time dependency in remagnetizations of Appalachian redbeds and limestones. If Oliver (1986) is correct that the remagnetization event is caused by fluid flow induced by the emplacement of thrust sheets, then we might infer from our analysis of the available paleomagnetic data that major thrusting and large-scale fluid migration ended near the Permian/Carboniferous boundary in the southern Appalachians and continued on through most of the Permian in the northern central Appalachians. This conclusion is consistent with stratigraphic and structural arguments for a south to north progression in relative timing of Alleghanian deformation (Rodgers, 1967; Dean et al., 1988).

Additional data are, of course, needed to confirm the apparent age progression in remagnetizations, especially from the southern Appalachians, as well as to describe any contributions from across-strike and stratigraphic variations in the nature of the remagnetization. However, we believe it is already evident that although the dating is indirect, remagnetizations have the potential to complement the use of radiochronology of authigenic minerals for dating the thermochemical imprint of orogenic fluid flow. Remagnetization components occur commonly in a variety of rock types and can also yield information on the relative timing of folding and fluid flow. Thus, remagnetization history holds promise as a tool for dating of structural events at both the regional and local scales.

\section{REFERENCES CITED}

Altaner, S.P., 1985, Potassium metasomatism and diffusion in Cretaceous K-bentonite from the disturbed belt, northwestern Montana, and in the Middle Devonian Tioga K-bentonite, eastern USA [Ph.D. thesis]: Urbana, University of Illinois, $193 \mathrm{p}$.

Bachtadse, V., Van der Voo, R., Haynes, F.M., and Kesler, S.E., 1987, Late Paleozoic magnetization of mineralized and unmineralized Ordovician carbonates from east Tennessee: Evidence for a post-ore chemical event: Journal of Geophysical Research, v. 92, p. 14165-14176.

Chen, D.L., and Schmidt, V.A., 1984, Paleomagnetism of the middle Mississippian Greenbrier Group in West Virginia, USA, in Van der Voo, R., Scotese, C.R., and Bonbommet, N., eds., Plate reconstruction from Paleozoic paleomagnetism: American Geophysical Union Geodynamics Series, v. 12, p. 48-62.

Dean, S.L., Kulander, B.R., and Skinner, J.M., 1988, Structural chronology of the Alleghanian orogeny in southeastern West Virginia: Geological Society of America Bulletin, v. 100, p. 299-310.

Dorobek, S.L., 1987, Petrography, geochemistry, and origin of burial diagenetic facies, Siluro-Devonian Helderberg Group (carbonate rocks), central Appalachians: American Association of Petroleum Geologists Bulletin, v. 71, p. 492-514.

Elliott, W.C., and Aronson, J.L., 1987, Alleghenian episode of K-bentonite illitization in the southern Appalachian Basin: Geology, v. 15, p. 735-739.

French, R.A., and Van der Voo, R., 1977, Remagnetization problems with the paleomagnetism of the Middle Silurian Rose Hill Formation of the cen- tral Appalachians: Journal of Geophysical Research, v. 82, p. 5803-5806.

Gillett, S.L., 1982, Paleomagnetism of the Late Cambrian Crepicephalus-Aphelaspis trilobite zone boundary in North America-Divergent poles from isochronous strata: Earth and Planetary Science Letters, v. 58, p. 383-394.

Gordon, R.G., Cox, A.V., and O'Hare, S., 1984, Paleomagnetic Euler poles and the apparent polar wander and absolute motion of North America since the Carboniferous: Tectonics, v. 3, p. 499-537.

Hearn, P.P., and Sutter, J.F., 1985, Authigenic potassium feldspar in Cambrian carbonates: Evidence of Alleghenian brine migration: Science, v. 228, p. 1529-1531.

Irving, E., and Irving, G.A., 1982, Apparent polar wander paths Carboniferous through Cenozoic and the assembly of Gondwana: Geophysical Surveys, no. 5, p. 141-188.

Kent, D.V., 1985, Thermoviscous remagnetization in some Appalachian limestones: Geophysical Research Letters, v. 12, p. 805-808

- 1988, Further paleomagnetic evidence for oroclinal rotation in the central folded Appalachians: Tectonics (in press).

Kent, D.V., and Miller, J.D., 1987, Redbeds and thermoviscous magnetization theory: Geophysical Research Letters, v. 13, p. 327-330.

Kent, D.V., and Opdyke, N.D., 1978, Paleomagnetism of the Devonian Catskill red beds: Evidence for motion of coastal New England-Canadian Maritime region relative to cratonic North America: Journal of Geophysical Research, v. 83, p. $4441-4450$.

- 1985, Multicomponent magnetizations from the Mississippian Mauch Chunk Formation of the central Appalachians and their tectonic implications: Journal of Geophysical Research, v. 90, p. 5371-5383.

Martin, D.L., 1975, A paleomagnetic polarity transition in the Devonian Columbus Limestone of Ohio: A possible stratigraphic tool: Tectonophysics, v. 28, p. 125-134

McCabe, C., Van der Voo, R., Peacor, D.R., Scotese, C.R., and Freeman, R., 1983, Diagenetic magnetite carries ancient yet secondary remanence in some Paleozoic sedimentary carbonates: Geology, v. 11, p. 221-223.

McCabe, C., Van der Voo, R., and Ballard, M.M. 1984, Late Paleozoic remagnetization of the Trenton Limestone: Geophysical Research Letters, v. 11, p. 979-982.

Miller, J.D., and Kent, D.V., 1986a, Synfolding and prefolding magnetizations in the Upper Devonian Catskill Formation of eastern Pennsylvania: Journal of Geophysical Research, v. 91, p. 12791-12803.

_ 1986b, Paleomagnetism of the Upper Devonian Catskill Formation from the southern limb of the Pennsylvania salient: Geophysical Research Letters, v. 13, p. 1173-1176.

-1988, Paleomagnetism of the Siluro-Devonian Andreas redbeds: Evidence for an Early Devonian supercontinent?: Geology, v. 16, p. 195-198.

\section{Reviewer's comment}

This paper has a very interesting conclusion, i.e., that the timing of the remagnetization varies along the Appalachians. This is an important piece of information and one that merits publication in Geology.

Jack Oliver
Oliver, J., 1986, Fluids expelled tectonically from orogenic belts: Their role in hydrocarbon migration and other geologic phenomena: Geology, v. 14, p. 99-102.

Perroud, H., and Van der Voo, R., 1984, Secondary magnetizations from the Clinton-type iron ores of the Silurian Red Mountain Formation, Alabama: Earth and Planetary Science Letters, v. 67 , p. 391-399.

Pullaiah, G., Irving, E., Buchan, K.L., and Dunlop, D.J., 1975, Magnetization changes caused by burial and uplift: Earth and Planetary Science Letters, v. 28, p. 122-143.

Rodgers, J., 1967, Chronology of tectonic movements in the Appalachian region of eastern North America: American Journal of Science, v. 265, p. 1967.

Roy, J.L., Opdyke, N.D., and Irving, E., 1967, Further paleomagnetic results from the Bloomsburg Formation: Journal of Geophysical Research, v. 72, p. 5075-5086.

Scotese, C.R., 1985, The assembly of Pangea: Middle and late Paleozoic paleomagnetic results from North America [Ph.D. thesis]: Chicago, Illinois, University of Chicago, $339 \mathrm{p}$.

Scotese, C.R., Van der Voo, R., and McCabe, C., 1982, Paleomagnetism of Upper Silurian and Lower Devonian carbonates of New York State: Evidence for secondary magnetizations residing in magnetite: Physics of the Earth and Planetary Interiors, v. 30, p. 385-395.

Stead, R.J., and Kodama, K.P., 1984, Paleomagnetism of the Cambrian rocks of the Great Valley of east-central Pennsylvania: Fold test constraints on the age of magnetization, in Van der Voo, $R$. Scotese, C.R., and Bonhommet, N., eds., Plate reconstruction from Paleozoic paleomagnetism: American Geophysical Union Geodynamics Series, v. 12, p. 120-130.

Van der Pluijm, B.A., 1987, Grain-scale deformation and the fold test-Evaluation of syn-folding remagnetization: Geophysical Research Letters, v. 14, p. 155-157.

Van der Voo, R., and French, R.B., 1977, Paleomagnetism of the Late Ordovician Juniata Formation and the remagnetization hypothesis: Journal of Geophysical Research, v. 82, p. 5796-5802.

Walton, D., 1982, Time-temperature relations in the magnetization of assemblies of single domain grains: Nature, v. 286, p. 245-247.

Watts, D.R., and Van der Voo, R., 1979, Paleomagnetic results from the Ordovician Moccasin, Bays, and Chapman Ridge formations of the Valley and Ridge province, eastern Tennessee: Journal of Geophysical Research, v. 84, p. 645-655.

\section{ACKNOWLEDGMENTS}

Supported by National Science Foundation Division of Earth Sciences Grant EAR-85-07046. We thank S. Halgedahl for a helpful review. LamontDoherty Geological Observatory Contribution 4270.

Manuscript received December 11, 1987

Revised manuscript received March 2, 1988

Manuscript accepted March 10, 1988 